\title{
Brokering Immigrant Worker Rights: An Examination of Local Immigration Control, Administrative Capacity and Civil Society
}

Shannon Gleeson

Cornell University

We know a great deal about the clash between federal immigration and labour standards enforcement directives, but less regarding how these two processes are functioning at the local level and the role that demographic factors and civil society play. This article examines the impact of a climate of local immigration enforcement on worker legal mobilisation in metropolitan statistical areas (MSAs) in the USA. I focus on national origin discrimination and find that MSAs with a 287(g) agreement within their boundaries have lower claims rates. Conversely, claims rates are higher in MSAs where an Equal Employment Opportunity Commission (EEOC) agency is present. Interactive models suggest a positive dynamic of demographic insulation, whereby the negative effect of local immigration enforcement on claims-making is diminished in more heavily Latino immigrant places, and the negative impact of a larger Latino immigrant workforce is mitigated with the presence of an enforcement agency. Civil society has a positive impact on claims-making, but with no evidence that $287(\mathrm{~g})$ MSAs with varying concentrations of civil society fare any better or worse. While previous research has concluded a positive impact of 501c(3) organisations on legal mobilisation, this more localised perspective reveals the continuing relevance of labour unions.

Keywords: Worker Legal Mobilisation; Local Immigration Enforcement; Civil Society

\section{Introduction}

The current national discussion has focused on the congressional impasse over immigration reform, though local communities continue to grapple with how to enforce the rights that are already in place for immigrants in a range of arenas, including the workplace. Yet, the goals of labour standards enforcement agencies (LSEAs) and immigration authorities have been largely at odds (Lee 2011; Griffith 2011a, 2012). Federal employer sanctions policies, once lauded by organised labour, are now seen as a tool of labour exploitation (Fox 2009; Rosenblum 2011), and unions today denounce them as harmful to 
efforts to organise immigrant workers. Beyond border militarisation and worksite enforcement programmes, this article takes into account the role of local immigration policy on worker legal mobilisation.

While scholars have examined the 'multi-layered jurisdictional patchwork' of policies that enhance federal immigration enforcement efforts (Varsanyi et al. 2012), a great deal of this focus has been on how everyday local policing becomes a deportation dragnet for undocumented immigrants with minor offenses (Armenta 2012). Alternatively, this article examines the role that the climate of local immigration control may have on rights enforcement beyond the criminal justice system. I assess how the presence of a $287(\mathrm{~g})$ agreement in a metropolitan statistical area (MSA) is associated with worker claims-making levels, specifically in the arena of national origin discrimination. I do so in relation to two key institutional resources for legal mobilisation: the administrative capacity of LSEAs and the presence of civil society advocates. I do so while also accounting for the ethnic and economic composition of the immigrant workforce.

In the pages that follow, I begin by providing readers with an overview of the factors that drive worker legal mobilisation and the specific context of employment discrimination law. I then lay out what we already know about the chilling effect of federal immigration enforcement on efforts to protect the rights of all workers, and how LSEAs have navigated these contradictory mandates to fulfil their own mission to advance worker rights. I assess several hypotheses regarding local immigration enforcement and administrative capacity for labour standards enforcement, on worker claims-making.

My findings confirm that those MSAs with a $287(\mathrm{~g})$ agreement within their boundaries have lower claims rates, while those with an Equal Employment Opportunity Commission (EEOC) office have higher claims rates. However, the impacts of both are mitigated in MSAs with denser Latino immigrant populations. Denser civil society networks (especially a stronger presence of labour unions) also have a 
positive effect. I conclude by suggesting a theoretical shift in how we conceptualise the factors that shape immigrant legal mobilisation and offer recommendations for future research.

\section{Literature Review}

\section{Legal Mobilisation and Worker Rights}

Much of what we know about the causes and effects of worker mobilisation draws from the social movement and labour union literature. Labour advocates in the USA have successfully demanded stronger protections via the courts in recent decades (Burstein 1991); however, there is an ongoing debate regarding whether these legal tactics dampen (Rosenberg 1991) or rejuvenate (McCann 1994) social movements. In industries with low union density, we know that worker movements are using the law in innovative ways alongside attempts at collective bargaining. For example, in the largely deregulated garment industry in Los Angeles, the anti-sweatshop movement has brought together activists and lawyers to use high-profile cases to achieve policy change with gains for individual workers (Cummings 2009). The needs of immigrant workers have been a central concern of these union efforts.

While private-sector union membership rates are not significantly different for native born (7.7\%) and foreign-born (7.6\%) workers, undocumented workers have posed a particular challenge for labour unions (Milkman 2011). In either case, the vast majority of immigrant workers are not unionized, as is the case for native-born workers. Lacking a collective bargaining contract, these workers must leverage legal protections for individual rights enforced by administrative bureaucracies such as the EEOC. Much of the research on employment discrimination has focused on the factors driving the success of litigation strategies, and we know from this work that having legal representation and pursuing a class action case (a rarely adopted strategy) is particularly beneficial (Burstein and Monaghan 1986; Nielsen and Nelson 2005; Berrey, Hoffman, and Nielsen 2012). However, litigation is not always successful; critics argue the judicial process 'seldom offers an authoritative resolution of whether 
discrimination occurred' and produces limited remedies for even successful claimants (Nielsen, Nelson, and Lancaster 2010, 177).

The structural limitations of the courts aside, LSEAs such as the EEOC struggle particularly to entice immigrant workers to come forward (Gordon 2007). Protections are limited in industries that are poorly covered by existing law, such as in the informal or cash economy where it can also be difficult to definitively prove the circumstances leading to a workplace violation. Restrictions on the remedies available to undocumented workers have further institutionalised these inequalities.1 In sum, we know that the conditions of workplace abuse are worse in industries with low wage immigrant populations; however, we know less about the contextual factors that shape immigrant worker legal mobilisation.

\section{The Chilling Effect of Local Immigration Enforcement}

We know that increased immigration enforcement efforts have had a sharply negative effect on the protection of immigrant worker rights, and that Immigration Customs Enforcement campaigns have interfered with efforts to enforce federal labour protections (Lee 2011; Griffith 2011a, 2012). Despite existing memoranda of understanding that require that immigration authorities coordinate with LSEAs to avoid disrupting ongoing investigations, in practice, this prior warning rarely happens. Advocates argue that immigration enforcement programmes have a chilling effect on workers' ability to complain against workplace violations such as wage theft, discrimination and unsafe working conditions and have made collective bargaining more challenging, despite several high-profile successes (Smith, Avendaño, and Ortega 2009).

Worksite programmes such as Social Security-No Match letters and E-Verify have received the bulk of attention with regard to the impacts of immigration enforcement campaigns (Fox 2009; Rosenblum 2011). A recent study of returnees at the border finds that immigrants from states that have enacted a mandatory E-Verify requirement (a programme which allows employers to screen the legal 
status of applicants at the point of hire) report greater fear of deportation and are less likely to move across states (Amuedo-Dorantes, Puttitanun, and Martinez-Donate 2013). Reflecting on the negative impact of programmes such as E-Verify, Massey (2013) remarks, 'the main effect of US enforcement policy today is thus to marginalise and terrify undocumented migrants while not affecting their access to public services or influencing their migratory intentions (1094).' Despite this important emphasis on worksite enforcement, less attention has been paid to the impact of community-wide policies such as 287(g) on worker claims-making. In the USA, local police were granted additional powers to carry out immigration enforcement as deputies of the federal government through the 1996 Illegal Immigration Reform and Immigrant Responsibility Act, which challenged the principles that grant the federal government ultimate authority to regulate immigration (Decker et al. 2009; Varsanyi et al. 2012; Lewis et al. 2013). One manifestation of this devolution of power was the voluntary $287(\mathrm{~g})$ programme, which can operate via either a jail or task-force model via city police, county sheriff or state law enforcement. The jail model of the $287(\mathrm{~g})$ programme allows officials to screen arrested individuals for immigration status and to issue detainers when booking them into jail on criminal charges. The task-force model allows state and local officers to screen and issue detainers out in the field during routing policing (Capps et al. 2011, 1). Localities can adopt either or both through a 'hybrid model' (60).

In the post-9/11 era, programmes such as $287(\mathrm{~g})$ were branded the 'latest manifestation of this taste for discrimination against immigrants in times of national crisis, real or perceived' (Wishnie 2004, 1104), and these programmes follow in a long history of racial profiling and selective enforcement on the part of US immigration authorities. Up to 89 counties ( $3 \%$ of all US counties) have applied for the 287(g) programme. These counties are on average four times bigger than non-applicant counties and tend to have larger relative foreign-born and Latino populations (Wong 2012, 747).4 Rather than enhancing the safety and security of communities, the $287(\mathrm{~g})$ programme has had a devastating effect on Latino communities, with one of the biggest concerns being racial profiling and discrimination 
(Lacayo 2010). These concerns continue even as the $287(\mathrm{~g})$ programme is being phased out in favour of the now mandatory Secure Communities programme.

There have been a handful of studies examining the relationship between $287(\mathrm{~g})$ and worker outcomes, focusing largely on dynamics of economic competition. For example, Wong (2012) concludes that African-American and White disadvantage relative to Latinos is not significantly related to the presence of a $287(\mathrm{~g})$ agreement. Parrado (2012) also concludes that 287(g) did not mitigate the negative effect of the recession on native-born workers, even in counties with strong enforcement outcomes (Dallas, Los Angeles, Riverside and Phoenix). Pham and Van (2010) similarly find little evidence that jurisdictions that have adopted anti-immigrant laws such as $287(\mathrm{~g})$ are better or worse off economically than those that have not. Focusing specifically on farm-workers, Kostandini et al. (2012) provide weak evidence for wage increases in counties that have adopted $287(\mathrm{~g})$ and in fact uncover declines in the years following adoption of the policy (14-15). In this article, I look beyond labour market outcomes to assess how a context of local immigration enforcement is related to worker claims-making in era of inadequate labour standards enforcement that leaves immigrant workers in particular unprotected (Bernhardt et al. 2008, 2009).

\section{Brokering Legal Mobilisation}

The administrative systems that regulate individual worker rights in the USA comprise wide-and often disjointed-networks of federal, state and local offices. This paper focuses on national origin discrimination protections, regulated under Title VII of the Civil Rights Act, which are enforced primarily by the EEOC. Pedriana and Stryker (2004) characterise the early years of the EEOC as relatively weak, lacking the 'money, personnel, bureaucratic development' needed to achieve bureaucratic goals (710). In 1966, the EEOC had only 30 investigators nationwide (712). In contrast, I enumerated 177 federal EEOC offices and state/local Fair Employment Practice Agencies as of 2010. Despite this expanded 
enforcement capacity, the EEOC, like so many other LSEAs, remains under-resourced relative to the scope of its mission and tends to be located in central cities, further disadvantaging remote populations. Enforcement agencies often have a wide-ranging jurisdiction, and the time and opportunity costs of filing claim in a far-flung agency can impact rates of legal mobilisation (Felstiner, Abel, and Sarat 1980), and be particularly onerous for low-wage populations (Merry 1990). For undocumented immigrant populations, filing a claim directly via a government agency is not likely to be appealing (Abrego 2008). For these individuals, institutional brokers become particularly important to help shepherd individuals through the claims making processes. Groups ranging from civil rights advocacy organisations to legal aid groups and unions all are important first lines of defense. In a declining era of unionisation, worker centres have become particularly important resources for individuals looking to defend their workplace rights (Fine 2006). For example, Fine and Gordon (2010) reveal three case studies where unions and worker centres have been integrated into enforcing the Fair Labor Standards Act. Similarly, Martin (2012) highlights the importance of 'migrant nonprofit organizations' for advancing the rights of precarious and immigrant workers. These civil society groups also have been proactive in helping to enforce workplace protections, as well as for monitoring the reach of immigration enforcement at the workplace (Fine 2011; Leitner and Strunk 2014).

\section{Hypotheses}

Given this extant research, the following hypotheses guide this empirical study regarding the relationship between the context of local immigration enforcement, the administrative capacity for labour standards enforcement, civil society density and worker mobilisation.

Local immigration enforcement is likely to have a negative impact on the claimsmaking of immigrant populations: 
H1a: The presence of a $287(\mathrm{~g})$ agreement will predict lower rates of national origin discrimination claims-making.

Immigrant populations, however, have a range of racial experiences, and we know that Latino immigrant workers are disproportionately likely to experience a chilling effect from local immigration enforcement:

H1b: The chilling effect of a $287(\mathrm{~g})$ agreement on worker claims-making will be accentuated in places where Latinos comprise a higher proportion of the immigrant population.

The administrative capacity of an enforcement agency is important for driving worker claims-making, and physical proximity is an important factor for outreach and monitoring activities:

H2a: The presence of an EEOC/FEPA office in an MSA will predict higher rates of worker claims-making.

Given that Latino immigrants are often vulnerable workers who comprise the largest proportion of the low-wage and undocumented workforce, LSEAs will be particularly important in places where they comprise a larger proportion of the immigrant workforce:

$H 2 b$ : The presence of an EEOC/FEPA office will positively mediate the generally negative impact of a larger Latino immigrant population on claims-making.

Government agencies alone are unable to make immigrant worker rights real, and rely often on the collaboration of institutional intermediaries for promoting worker claims-making:

H3: A denser concentration of civil society organisations will predict higher levels of national origin discrimination claims-making. 


\section{Methodology}

\section{Empirical Model}

This study relies on a negative binomial regression count model applied to cross-sectional dataset of 272 completely identified MSA's, as defined by the US Census Bureau in 2010. Below I present descriptive and multivariate results.

\section{Dependent Variable: National Origin Discrimination}

The focus of this study is variation in the level of national origin claims, protected under Title VII of the Civil Rights Act. The EEOC enforces national origin discrimination protections, which include prohibitions against employment decisions based on national origin, harassment such as ethnic slurs and instances of language discrimination that are not deemed a 'bona fide occupational qualification' (such as accent discrimination, English fluency and English-only rules). The law covers all individuals regardless of citizenship status, though the 2002 Supreme Court Hoffman Plastics v. National Labor Relations Board decision limits relief for undocumented workers under the 1986 Immigration Reform and Control Act (Equal Employment Opportunity Commission 2010, 2014a, 2014b; Garcia 2012). Despite these restrictions, the law provides an important basis for immigrant worker claims-making (Chen 2012).

National-origin discrimination protections have been interpreted widely and ruled to not necessarily be coterminous with nativity or citizenship. In fact, many different types of workers may file national origin discrimination claims, including for example, an immigrant engineer, a secondgeneration Mexican-American, or an undocumented farmworker. National origin claims also are not 
mutually exclusive from other claims, although Best et al. (2011) conclude that such 'intersectional claims' are less likely to succeed. According to the most recent data available for this study, 10 of the 8737 claims filed in the first quarter of 2011, 2952 were also filed as cross-filed as race discrimination, 1408 as sex discrimination, 1296 as age discrimination, 903 as religious discrimination, 836 as disability discrimination and 678 as colour discrimination claims. Additionally, 3212 were registered as retaliation, and 288 as sexual harassment claims.

Arguably, other claims types capture different dimensions of workplace violations. For example, the epidemic of wage theft has garnered significant attention in recent years (Bobo 2008), as has the fact that foreign-born Latino workers have the highest levels of occupational injuries and illnesses (American Public Health Association 2005). Yet, the data sources for these types of claims are spread across various federal and state-specific agencies and lack good national coverage.

Furthermore, while the bar to filing a discrimination claim may be higher, and perhaps a lower priority for an aggrieved worker seeking to recover wages or medical treatment for an immediate injury, I argue that national origin discrimination claims represent exactly the type of worker claims-making that requires prolonged interaction with the administrative courts system, and which benefit significantly from legal brokers.

For this analysis, I rely on data obtained through a Public Records Request for 'charge receipts' from EEOC offices and their sister state/local Fair Employment Protection Agencies (FEPA). I calculate the average number of national origin discrimination claims from 2006 to 2010. I utilise a negative binomial regression to model the count of claims filed in a given MSA and rely on the size of the immigrant workforce to control for variation in the general 'population at risk' of filing a claim (exposure variable). While there is significant debate regarding how to interpret claims-levels, scholars have argued that claims-driven enforcement regimes such as Title VII are an appropriate measure of legal mobilisation (e.g. Nielsen, Nelson, and Lancaster 2010; Hirsh 2014). 


\section{Key Independent Variables}

Local Immigration Enforcement

In this study, I measure the context of local immigration enforcement according to the presence of a 287(g) agreement within an MSA. As described above, $287(\mathrm{~g})$ agreements were a key tool in the wake of the 1996 Illegal Immigration Reform and Immigrant Responsibility Act (IIRIRA) used to surveil and control immigrant communities. These agreements are certainly not the only way that the federal government has extended its reach beyond the border. Other post-IIRIRA programmes include worksite programmes such as E-Verify, the Social Security No-Match Letter programme and employer audits. Local and state governments have also adopted legislation to either facilitate immigrant integration or make life harder for undocumented residents. However, of those related specifically to local immigration enforcement, such as Arizona's controversial Senate Bill 1070 and Hazelton, Pennsylvania's restrictive housing law, many have been declared unconstitutional in whole or part, and were never implemented due to litigation.

In this paper, my interest is specifically on the local climate and reality of immigration detention and removal practices. Accounting for the presence of a 287(g) agreement allows me to capture those geographies that sought sanctioned relationships with federal authorities to participate in immigration enforcement. Though voluntary 287(g) agreements began being phased out in 2012 in favour of the now nearly universally required Secure Communities Program, they represent a unique historical moment when local governments could articulate this preference. Labour standards enforcement bodies such as the EEOC or its sister FEPAs are not governed directly by $287(\mathrm{~g})$, nor do any federal immigration policies mandate direct EEOC/FEPA participation in detention and deportation efforts. For this analysis, I draw from the compendium of $287(\mathrm{~g})$ agreements published by the Migration Policy Institute, drawn from Immigration Customs Enforcement Data (Capps et al. 2011, 
Appendix 2). An MSA was assigned a ' 1 ' if a $287(\mathrm{~g})$ agreement was in effect via any of these

mechanisms. In other words, MSAs that either completely or partially contained a city, county or state with a $287(\mathrm{~g})$ agreement were identified and attributed with that agreement. This yields 74 MSAs in total.

Resources for Claims-making: Administrative Capacity and Civil Society

I also control for two important claims-making resources: administrative capacity for labour standards enforcement and density of civil society. In the first, I record the presence of a federal EEOC or state/local FEPA office within an MSA. This information is published on the EEOC website, and I used GIS (Geographic Information Systems) to assign each office to an MSA based on office address information. While the EEOC structure changed significantly in 2006, the office/address data I use are up to date, and I have confirmed that they have not changed since fiscal year 2010.

Second, given the importance of bureaucratic brokers for individual claims-making, I also include a measure of the size of civil society within an MSA. To do so, I draw on data from IRS filings of registered 501c organisations published by the National Center for Charitable Statistics at the Urban Institute. I include counts from three different National Taxonomy of Exempt Entities (NTEE) categories relevant to immigrant worker legal mobilisation: I. Crime and Legal-Related $(01,80,83)$; J. Employment $(01,40) ;$ and R. Civil Rights, Social Action, Advocacy $(01,20,21,22,29)$. These counts were cumulated from data in the 2010 Business Master File and standardised by the size of the total workforce in each MSA.

\section{Controls}

Additionally, I control for (1) the economic status of the immigrant workforce in an MSA (measured by the logged average wages of immigrant workers) and (2) the ethnic composition of the immigrant workforce (measured by the proportion of immigrant workers who identify as Hispanic/Latino). These 
two measures are constructed from the ACS, which has now replaced the long form of the decennial census, resulting in an analytical tradeoff of providing more up-to-date data, in exchange for smaller sample sizes. I use the 2006-2010 multi-year ACS data, which provide a period estimate that describes the average population characteristics over these five years, and are most appropriately used for analysing small populations (American Community Survey 2013). Summary counts are compiled using the 'replicate weights' structure recommended by the ACS using the series of 'repwtp*' variables (Coursolle, Cleveland, and Ruggles 2013; IPUMS-USA 2013) and control for the clustered errors of the MSA variable (Federal Information Processing Standards, FIPS).

The ACS data I use come from the widely used Integrated Public Use Microdata Series (IPUMSUSA) at the Minnesota Population Center. The great utility of IPUMS data is that they harmonise data across years; however, in doing so must also account for changes over time in census geography. In order to reflect these shifts, I utilized the 'translation table' for the IPUMS variable METAREAD (which identifies MSAs using the 2000 census definitions). In alternative models, I also account for the presence of incompletely identified MSAs in the ACS by inflating population counts of foreign-born workers according to the published undercount rates. One could argue that this adjustment is erroneous, since the incompletely identified areas are not randomly distributed, and foreign-born individuals even less so. However, I argue that this bias produces a conservative estimate, given that the inflation factor is likely to over-estimate the size of the foreign-born population and in turn artificially deflate the rate of national origin discrimination claims included in these analyses. In the negative binomial regressions presented below, I limit this analysis only to those MSAs that could be completely identified in the American Community Survey (ACS) 2006-2010 five-year sample.

\section{Findings}

While the highest count of national origin discrimination claims can be found in the largest immigrant 
gateway metropolitan areas (Singer 2009), when adjusted by the size of the foreign-born workforce, the claims rate reveals a markedly different distribution (see Figure 1).

\section{Local Immigration Enforcement}

Seventy-four of the 272 MSAs in this sample have a $287(\mathrm{~g})$ agreement in place. Of these, 25 MSAs have a Jail Enforcement agreement, 55 have a Task Force agreement and 8 have a hybrid Jail \& Task Force agreement (see Capps et al. 2011, Appendix 2). Places where a 287(g) agreement has been adopted include not only immigrant hubs such as Los Angeles and Houston, but also new destinations such as Duluth-Superior, MN-WI, Albany, GA, and Memphis, TN-AR-MS (see Figure 2). MSAs with a

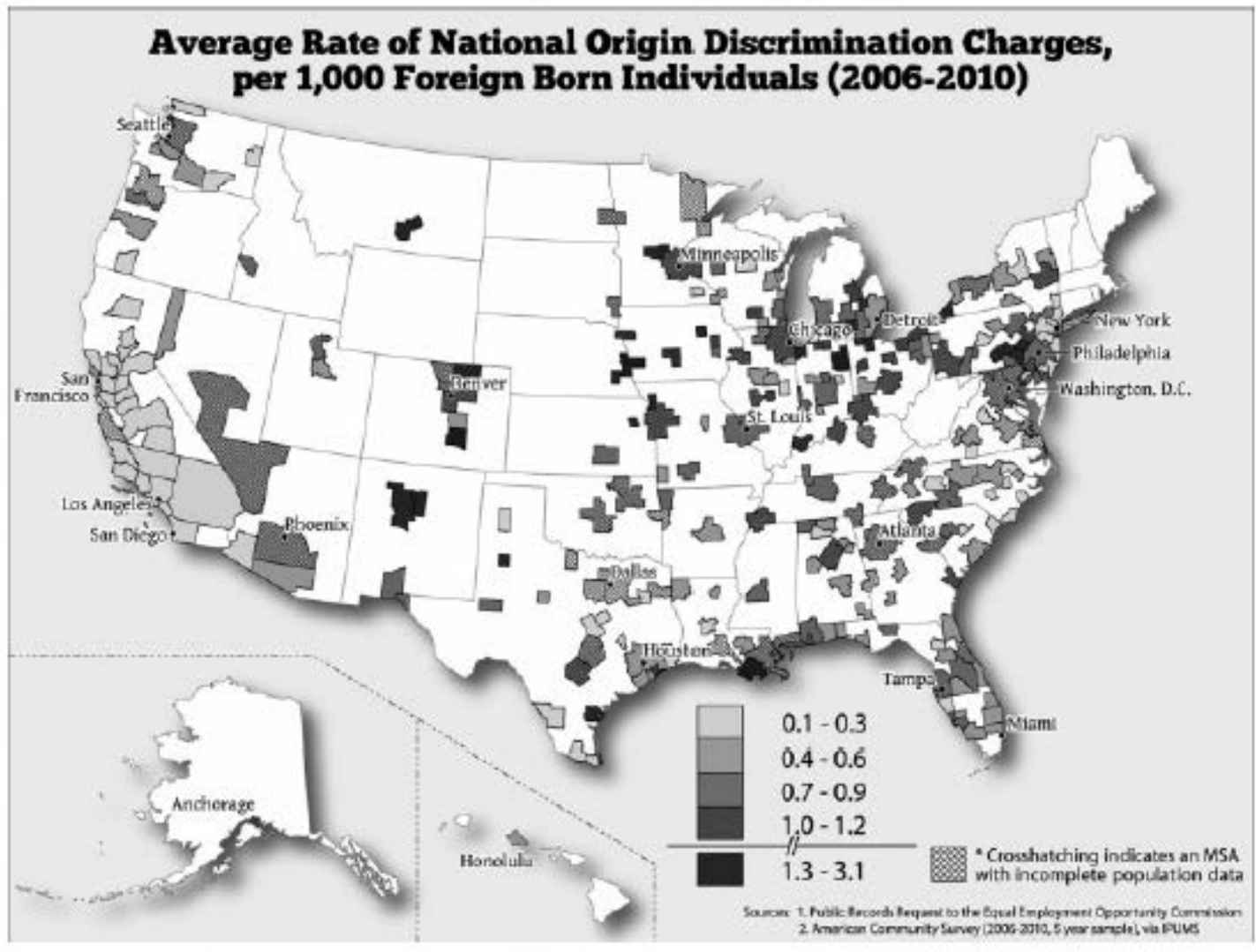

Figure 1. Average rate of National Origin Discrimination Charges, per 1000 foreignborn individuals in the Labor Force (2006-2010). 


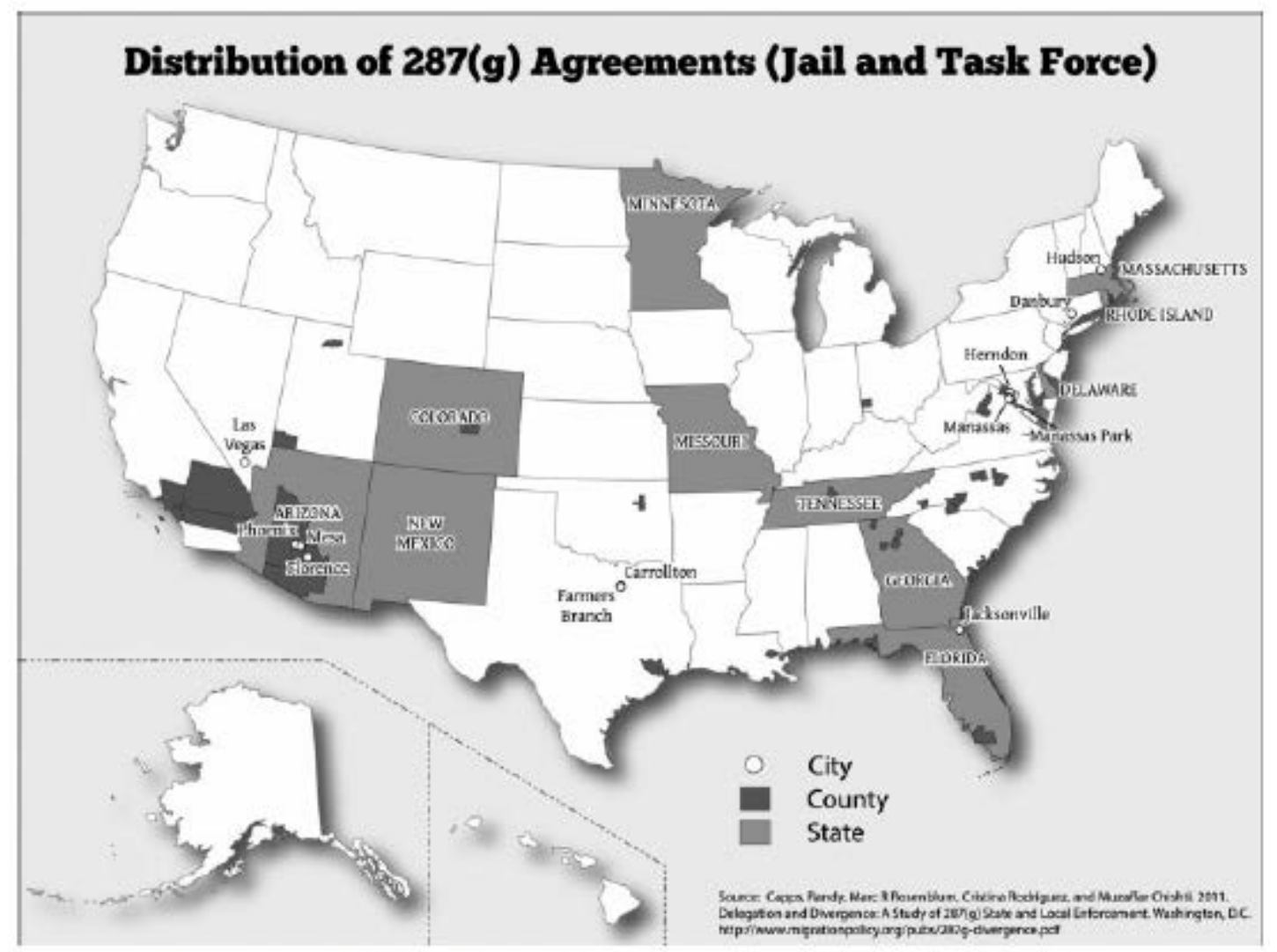

Figure 2. Distribution of $287(\mathrm{~g})$ Agreements (Jail and Task Force).

$287(\mathrm{~g})$ agreement in place, unsurprisingly, had on average larger immigrant workforces $(14.5 \%$ versus 11.6\%), but roughly equal proportions of Hispanic/Latino workers in the immigrant workforce overall (42.2\% versus $40.6 \%)$. (None of these differences, however, are statistically significant.)

When examined in a multivariate context, the presence of a $287(\mathrm{~g})$ agreement does not independently predict a higher rate of national-origin claims-making. However, when allowed to vary according to the per cent of the foreign-born workforce that is Hispanic/Latino, Model 2 (Table 1) reveals that the negative impact of local immigration enforcement on worker claims-making shrinks in places where Latinos comprise a larger proportion of the immigrant workforce. That is, MSAs with 287(g) agreements tend to fare better on worker claims when they have proportionally larger Hispanic/Latino immigrant populations. Therefore, despite the potential chilling effect of local immigration enforcement for the legal mobilisation of immigrant origin workers, there seems to be an 
insulating effect in places where the immigrant workforce is more homogenously Latino. In general, these findings confirm Hypothesis 1a; however, the mediating effect of a larger Latino immigrant workforce contradicts the prediction laid out in Hypothesis $1 \mathrm{~b}$, where I surmise that the negative effect of a $287(\mathrm{~g})$ agreement would be enhanced in larger Latino immigrant workforces. This could be due to two potential factors. In the first scenario, the negative impacts of police participation in immigration enforcement may be diminished given a critical mass of a particular racialised population. In the second, it may merely be that the availability of social networks to disseminate information and the cultural and linguistic resources are greater in more homogenous immigrant populations.

Table 1. Negative binomial regression results-factors shaping national origin discrimination claims rate for MSAs.

\begin{tabular}{|c|c|c|c|c|c|c|c|c|}
\hline Model & (1) & (2) & (3) & (4) & (5) & (6) & (7) & (8) \\
\hline $\begin{array}{l}\text { Presence of a } 287(\mathrm{~g}) \text { agreement } \\
\text { (jail or task force) within } \\
\text { an MSA }\end{array}$ & $0.073(0.094)$ & $-0.737^{* * *}(0.229)$ & $0.036(0.094)$ & $0.163^{*}(0.095)$ & $0.286^{*}(0.165)$ & $0.083(0.094)$ & $0.159^{*}(0.095)$ & $0.159^{*}(0.095)$ \\
\hline $\begin{array}{l}\text { Presence of a EEOC or FEPA } \\
\text { within an MSA }\end{array}$ & $0.313^{* * *}(0.089)$ & $0.269^{* * *}(0.088)$ & $-0.114(0.200)$ & $0.347^{* * *}(0.087)$ & $0.342^{* * *}(0.087)$ & $0.301^{* * *}(0.089)$ & $0.357^{* * *}(0.088)$ & $0.358^{* * *}(0.089)$ \\
\hline $\begin{array}{l}\% \text { of foreign-born labour force } \\
\text { that is Hispanic }\end{array}$ & $-0.511^{*}(0.305)$ & $-0.950^{* * *}(0.320)$ & $-0.859^{* *}(0.334)$ & $-0.218(0.309)$ & $-0.208(0.310)$ & $-0.514^{*}(0.306)$ & $-0.187(0.313)$ & $-0.185(0.315)$ \\
\hline $\begin{array}{l}\text { Logged average wage and salary } \\
\text { income (foreign-born) }\end{array}$ & $-0.074(0.293)$ & $-0.077(0.288)$ & $-0.113(0.289)$ & $-0.108(0.287)$ & $-0.092(0.287)$ & $-0.083(0.294)$ & $-0.082(0.288)$ & $-0.082(0.288)$ \\
\hline $\begin{array}{l}\% \text { of foreign-born labour force } \\
\text { that is Hispanic } \times \text { presence } \\
\text { of a } 287(\mathrm{~g} \text { ) agreement (jail or } \\
\text { task force) within an MSA }\end{array}$ & & $1.831^{* * *}(0.485)$ & & & & & & \\
\hline $\begin{array}{l}\% \text { of foreign-born labour force } \\
\text { that is Hispanic } \times \text { presence } \\
\text { of a EEOC or FEPA within } \\
\text { an MSA }\end{array}$ & & & $1.028^{* *}(0.438)$ & & & & & \\
\hline $\begin{array}{l}\text { \# of avil society orgs per } 1000 \\
\text { workers in MSA (all) }\end{array}$ & & & & $0.829^{* * *}(0.237)$ & $0.924^{* * *}(0.263)$ & & & \\
\hline $\begin{array}{l}\text { \# of avil society orgs per } 1000 \\
\text { workers in MSA (all) } \times \\
\text { presence of a } 287(\mathrm{~g}) \\
\text { agreement (jail or task force) } \\
\text { within an MSA }\end{array}$ & & & & & $-0.501(0.544)$ & & & \\
\hline $\begin{array}{c}\# \text { of avil society orgs per } 1000 \\
\text { workers in MSA }(501(c) 3)\end{array}$ & & & & & & $0.016(0.018)$ & & $-0.001(0.019)$ \\
\hline $\begin{array}{l}\text { \# of avil society orgs per } 1000 \\
\text { workers in MSA (labour } \\
\text { union) }\end{array}$ & & & & & & & $0.941^{* * *}(0.281)$ & $0.945^{* * *}(0.288)$ \\
\hline Constant & $-6.224^{* *}(3.097)$ & $-5.992 *(3.041)$ & $-5.663^{*}(3.055)$ & $-6.305^{* *}(3.035)$ & $-6.501 * *(3.039)$ & $-6.179 * *(3.101)$ & $-6.542^{* *}(3.043)$ & $-6.547^{* *}(3.044)$ \\
\hline Observations & 272 & 272 & 272 & 272 & 272 & 272 & 272 & 272 \\
\hline
\end{tabular}

\section{Administrative Capacity for Labour Standards Enforcement}

While local immigration enforcement may impede worker claims-making, the presence of a government enforcement agency is critical for propelling claimsmaking. Title VII of the Civil Rights Act is enforced across the USA by a patchwork of federal and state agencies. A federal EEOC office or 
state/local FEPA is located in a third of the 272 MSAs in this study, and of those 91 that do, 50 have only one office. The average size of the labour force in MSAs with an EEOC/FEPA is larger

$(905,582$ versus 176,615$)$, as is the proportion of the workforce that is foreign-born

(15\% versus $11 \%)$. The exposure variable on the negative binomial regression model accounts for this variation.

Recent claims data reveals an uneven distribution of claims processing by EEOC/ FEPA office (see Figure 3). Take for instance the New York District, which covers 12 federal, state and local offices within its jurisdiction. This district processed the largest number of claims during the first quarter of

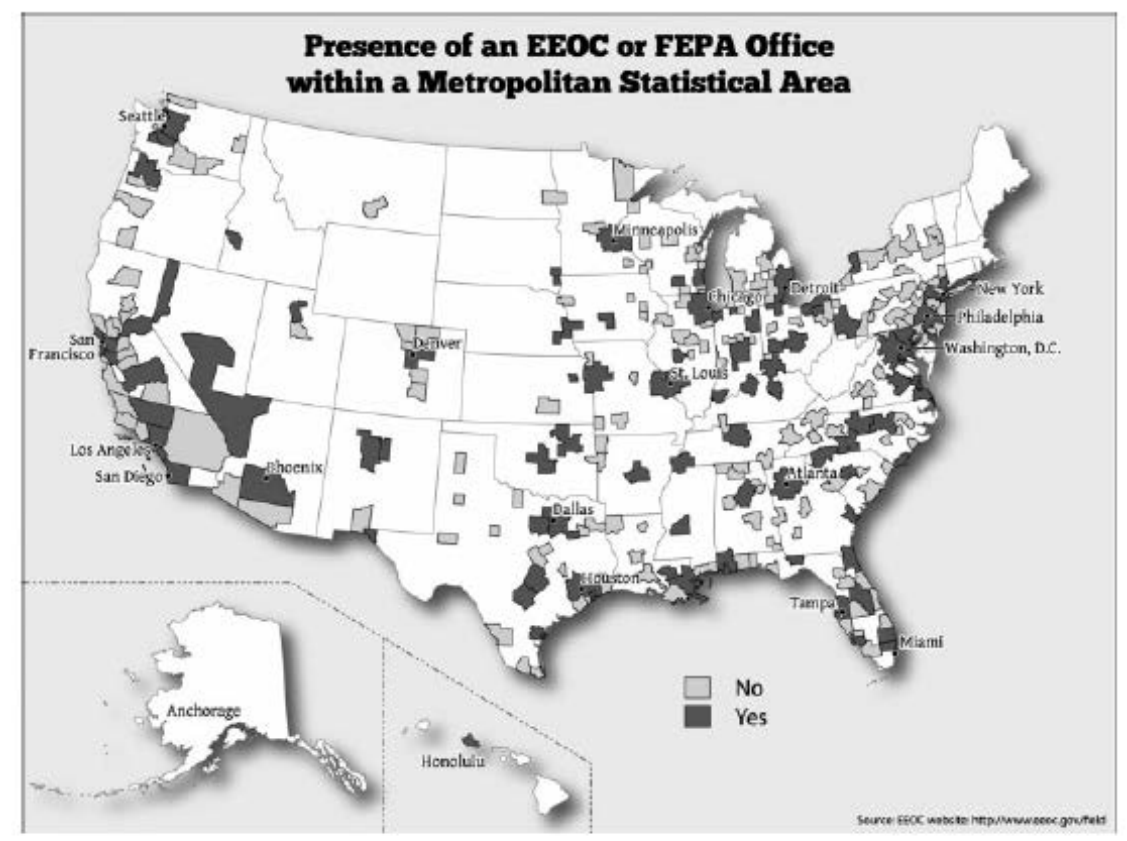

Figure 3. Presence of an EEOC or FEPA Office within an MSA.

2011 (348 of the 1285); however, the state agencies with which it coordinates also played a very important role. Yet, not all MSAs have an office within their borders, thus creating at least two practical challenges for claimants. First, state and local agencies sometimes enforce statutes that are more generous than the federal law, and are often more accessible beyond the big central cities where 
federal offices tend to be located. Second, state and local agencies provide an important claims-making venue for undocumented immigrants who may be reticent to approach a federal agency that they perceive is more closely associated with federal immigration enforcement authorities.

Even when viewed from a bivariate perspective the presence of either an EEOC or FEPA in an MSA seems to matter for claims-making. MSAs with an EEOC/FEPA had on average 1.1 claims per 1000 foreign workers, compared to 0.84 claims for those MSAs without an EEOC/FEPA. Multivariate results reaffirm a persistent positive impact of having an EEOC/FEPA present in an MSA, even when adjusting for the size of the workforce and the average economic status of immigrant workers, confirming Hypothesis 2a. Similar to the interactive effect of population composition and the presence of a $287(\mathrm{~g})$ agreement, the importance of an EEOC/FEPA office varies according to the size of the Latino immigrant workforce. While the main effect of an EEOC/FEPA office is not statistically significant in the interactive Model 3, the interaction with the size of the Latino/immigrant workforce is positive. This lends support for Hypothesis $2 b$, which assumed an enhanced importance for these agencies in immigrant populations that were more heavily Latino. This implies that government agencies can indeed mediate low levels of claims-making amongst vulnerable immigrant populations.

\section{Density of Civil Society}

Beyond the importance of formal enforcement bureaucracies, past research has highlighted the importance of nonprofit institutional intermediaries (e.g. Fine and Gordon 2010). However, as is the case with government enforcement agencies, civil society groups are not equally distributed across the USA (see Figure 4). During this study period, there was an average of 99 relevant civil society organisations per MSA. These were mostly labour union organisations (71) or other 501c categories such as policy advocacy groups (85), but with fewer nonprofit 501(c)3 service organisations (14). The distribution of these worker-oriented nonprofit organisations also varied according to whether there 
was an EEOC/FEPA present in the MSA. Those MSAs with an EEOC/FEPA had on average 194 nonprofit groups (29.4 per 100,000 workers), compared to 52 in MSAs without an EEOC/FEPA (34.7 per 100,000 workers.) Corroborating previous research on the importance of civil society for promoting claimsmaking, multivariate results confirm Hypothesis 3 that even when controlling for the presence of an EEOC/FEPA, the density of civil society has an independent positive impact on claims making.

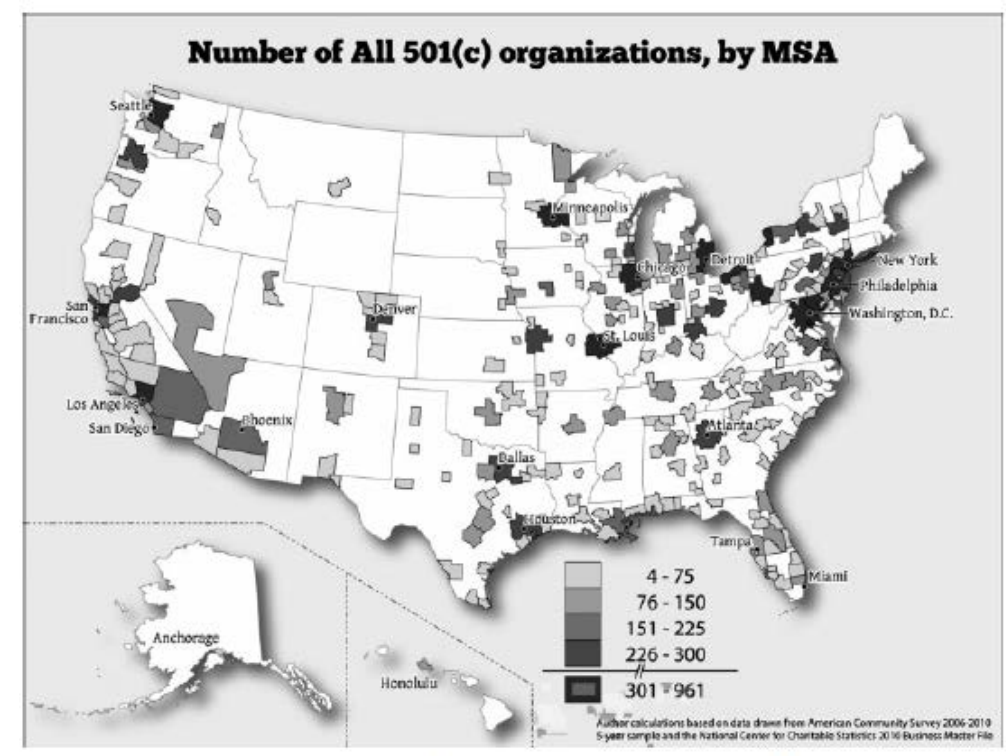

Figure 4. Number of all 501(c) organisations, by MSA.

I also examined the interactive impact of civil society density and the presence of local immigration enforcement policies, which have been the target of persistent immigrant organising. Unsurprisingly, given that MSAs with a $287(\mathrm{~g})$ agreement have larger populations, they on average also have more civil society organisations (121 versus 87 groups on average). However, when adjusting for the size of the workforce, MSAs with a $287(\mathrm{~g})$ agreement within its boundaries have less dense civil societies (24.8 versus 37.4 per 100,000 workers). Model 5 reveals that while the density of civil society has a positive impact on claims-making, there is no evidence that 287(g) MSAs with varying civil society densities fare any better or worse. 
Though socio-legal scholarship has emphasised the importance of legal aid clinics and the growing number of non-union worker centres, a closer look at the impact of varying types of nonprofit groups reveals that traditional labour unions may still have an important role to play in promoting individual worker claims-making. This finding may seem counterintuitive, given that at the individual level, traditional labour unions provide few if any direct services for workers beyond their membership. As explained above, traditional labour unions represent a diminishing proportion of the workforce (7.5\% of the private sector in 2013 , compared to $18.5 \%$ in 1983) (Hirsch and Macpherson 2012). As a whole, immigrant workers are even less likely to be represented by a labour union than are native-born workers (9.0\% versus $12.6 \%)$, even though they comprise a larger proportion of the union workforce than they did in the past (Batalova 2011), and there is greater parity in the private sector (Milkman 2011). Further, union members who have experienced a workplace violation typically must go through their internal grievance process with the support of their union.

However, these facts do not negate the political importance of unions as organisations and their capacity to advocate far beyond their immediate membership. Unions have pursued two channels for promoting immigrant worker rights over the last several decades. The first is through outreach partnerships with LSEAs, including the EEOC. For example, central labour councils and affiliated unions play an important role in educating immigrant workers about their rights through community events such as the annual Labor Rights Week, sponsored by the Mexican Consulate (e.g. Justice for Carwash Workers 2011). A second important role that unions play in promoting immigrant worker rights is through monitoring immigration enforcement efforts and ensuring access to LSEAs. Although the AFL$\mathrm{CIO}$ has partnered with policy advocates at the national level to highlight how immigration enforcement has interfered with worker rights (Smith, Avendaño, and Ortega 2009), local unions also play an important watchdog role to hold both LSEAs and immigration authorities accountable (e.g. Parra-Garcia 2012). In sum, while previous state-level analyses have confirmed the importance of 
510c(3) organisations for promoting claims-making, central labour councils and affiliated locals may provide particularly important worker outreach and agency monitoring at the local level, despite declining memberships.

\section{Conclusions and Directions for Future Research}

The findings presented here provide evidence that local immigration enforcement may well be detrimental for immigrant worker claims-making, and that proximate administrative capacity matters for promoting worker claims-making, particularly for vulnerable workers. This suggests that Griffith (2011b) and Lee (2011)'s argument in favour of a role for standards enforcement agencies to monitor immigration enforcement would be an important step towards more fully enforcing immigrant worker rights. However, government agencies alone are not sufficient. Institutional intermediaries matter for shepherding individual claims through the formal bureaucracy. While worker centres and other policy groups may play an important role, these findings suggest that labour unions will likely continue to play a strong force for labour standards enforcement even beyond the collective bargaining contracts they provide their members.

Moving forward, future analyses should certainly investigate the role of other forms of worker claims-making. Despite its important qualities for comparative analysis, national-origin discrimination claims are a limited a proxy for low-wage immigrant worker legal mobilisation. However, several data challenges remain in making this shift. While data on wage and hour violations represent the most common type of workplace claim, existing data are very disjointed across geographic and legal jurisdiction. The now publicly available Department of Labor (DOL) WHISARD database is an important source for tracking federal wage and hour claims, but unlike the EEOC and FEPA claims, these data do not include those claims filed with state and local agencies (including the now five cities that have a 
local minimum wage). Similarly, health and safety claims, such as workers' compensation reports are mostly state regulated, making national analyses across diverse populations challenging.

Beyond the challenge of accurately measuring worker legal mobilisation, we might ask whether $287(\mathrm{~g})$ is an adequate measure of how workers experience local immigration enforcement efforts. It is possible that $287(\mathrm{~g})$ agreements do not directly affect workplace experiences. One may argue that detailed data on worksite enforcement (see Lee 2011) would better capture how individuals are experiencing immigration enforcement efforts as it relates to workplace claims.29 Yet, the unique period when $287(\mathrm{~g})$ was active on a voluntary basis, on the eve of the now uniform Secure Communities programme, provides an important empirical opportunity to measure the political will for collaborating with federal immigration enforcement efforts and the context of immigrant reception.30 As such, I would argue that worker experiences are shaped by, and in turn influence, factors far beyond their specific worksite and work hours. Policies adopted by local officials also set an important tone for employers and the broader public (Singer, Wilson, and DeRenzis 2009) and should not be overlooked when assessing ways to improve immigrant worker experiences.

Lastly, while this research focuses on administrative capacity and the presence of civil society advocacy organisations in an MSA, future work should also examine the role of the for-profit legal community, which is missing from this analysis. Particularly in the case of national origin discrimination, which often requires litigation in superior court, private counsel is an important, albeit difficult to measure, resource. No matter how well intentioned the nonprofit advocacy community is, their capacity pales in comparison with the private sector. Private sector attorney, who plays an important role in public interest law (Nielsen and Albiston 2006), will remain a key aspect of labour standards enforcement efforts that rely heavily on settlement hearings and litigation. 


\section{Acknowledgements}

Author would like to thank Jared Moreno for research assistance, Doug Niven for technical assistance, to Barry Nickel and Aaron Coale for superb GIS assistance, and to Amada Armenta, Emilio Parrado, Juan Pedroza for help throughout the development of this manuscript. An earlier version of this article was presented, and benefitted from, a panel at the 2013 Law and Society Association Annual Meeting, chaired by Mike Wishnie.

\section{Notes}

[1] The Supreme Court decision Hoffman Plastic Compounds, Inc. v. National Labor Relations Board (00-1595) 535 US 137 (2002) barred undocumented workers from receiving back pay or reinstatement and has been widely criticised for promoting workplace exploitation (e.g. Fisk, Cooper, and Wishnie 2005). One attempt to address the widespread retaliatory threats that undocumented workers receive is through immigration relief mechanisms such as the U-Visa (Saucedo 2010; Cho and Smith 2013).

[2] Based on correspondence with National Employment Law Project DOL and Retaliation working group, 5/12/12.

[3] The recent pattern of devolution of immigration control to local governments is not unique to the USA (Lahav 1998; Guiraudon and Lahav 2000).

[4] To be sure, not all $287(\mathrm{~g})$ programmes have yielded equal levels of deportation, with the highest volumes coming from Arizona, California and Texas (US Immigration and Customs Enforcement 2010).

[5] Pham and Van (2010) conclude a negative to small effect: a 1-2\% drop in employment and a payroll drop of between $0.8 \%$ and $1.9 \%$ for both authorised and unauthorised workers, with uneven effects across industries (486).

[6] The EEOC and the US Department of Justice (DOJ) Civil Rights Division Office of Special Counsel for Immigration-Related Unfair Labor Practices both enforce protections against national origin discrimination project. However, the DOJ is tasked specifically with processing claims against establishments with between 4 and 14 employees and other claims outside of the jurisdiction of the EEOC (Griffith 2011b, 1143-1444, footnotes 47-50). See also the 2000 'Memorandum of Understanding Between The EEOC and The Office of Special Counsel for Immigration Related Unfair Employment Practices' (Equal Employment Opportunity Commission 2000).

[7] See, for example: http://www.browardbar.org/articles/84.html.

[8] See, for example: Gritter (2012).

[9] See, for example: Tamayo (1999). 
[10] Data is for the first quarter of 2011 (3/31/11).

[11] EEOCs and FEPAs cross-file their statutory claims, thus comprising a more comprehensive overview of claims across federal, state, and local jurisdictions.

[12] Pham and Van (2010)'s Immigrants Climate Index relies on a range of sub federal indicators such as access to social benefits, workplace protections, housing, immigrant integration programmes, educational access and drivers' licences. According to the National Conference of State Legislatures, in 2013, 'lawmakers in 45 states and the District of Columbia enacted 184 laws and 253 resolutions related to immigration' (National Conference of State Legislatures 2014).

[13] Past analyses have examined the impact of the 287 (g) programme using both county (Wong 2012) and metropolitan area (Parrado 2012) data.

[14] These categories specifically include the following 'Core Codes': I. Crime and Legal-Related (I01 Alliances \& Advocacy, 180 Legal Services, 183 Public Interest Law); J. Employment (J01 Alliances \& Advocacy, J40 Labor Unions); R. Civil Rights, Social Action, Advocacy (R01 Alliances \& Advocacy, R20 Civil Rights, R21 Immigrants' Rights, R22 Minority Rights, R29 Employee and Workers' Rights). Note: R21 and R29 are draft codes not used by the Internal Revenue Service. A more detailed overview of NTEE codes can be found here: http://nccs.urban.org/classification/NTEE.cfm.

[15] In these models, I also test for the presence of a state-level Right to Work law, which restricts collective bargaining efforts. These findings were consistently insignificant and did not change the overall findings, and therefore I do not report on them here.

[16] svyset FIPS [pweight=perwt], vce(brr) brrweight(repwtp1-repwtp80) fay(.5)mse.

[17] This yielded 22 MSAs that had to be recoded for this analysis, limited to those MSAs for which I had EEOC data available.

[18] To make this adjustment, I divided the weighted count by the reciprocal of the under coverage factor. The published list may be found here: https://usa.ipums.org/usa/volii/ incompmetareas.shtml.

[19] In order to correctly account for complex survey design of the ACS, I use the sub pop adjustment with svyset svy commands, to limit the sample to individuals who are foreign born, between the ages of 25 and 64, and who do not live in group quarters (i.e. if gq =0 \& gq =3 \& gq =4). For analyses using similar sample limitation conventions, see, for example: Borjas, Grogger, and Hanson (2008); Ottaviano and Peri (2008); Dadson (2012).

[20] The MSAs with the top 10 average number of national origin claims from 2006 to 2010 are: \#263 Orlando, FL (260.8), \#264 Denver, CO (290.8), \#265 Philadelphia, PA-NJ (315.4), \#266 Atlanta, GA (380), \#267 Phoenix-Mesa, AZ (392), \#268 Los Angeles-Long Beach, CA (430), \#269 Houston, TX (446), \#270 Washington, DC-MD-VA-WV (539), \#271 New York, NY (967.8), \#272 Chicago, IL (1053.4).

[21] The MSAs with the top 10 average number of national origin claims per 1000 foreign-born workers from 2006 to 2010 are not traditional immigrant gateways: \#263 Fort Wayne, IN (2.9), \#264. Harrisburg-Lebanon-Carlisle, PA (2.9), \#265 Jamestown, NY (2.9), \#266 Toledo, OH (3.1), \#267 Reading, PA (3.1), \#268 Billings, MT (3.2), \#269 Albuquerque, NM (3.4), \#270 Santa Fe, NM (3.7), \#271 Corpus Christi, TX (3.8), \#272 Pueblo, CO ( 5.6); compared to much lower rates in the traditional immigrant receiving gateways mentioned above: \#192 Orlando, FL (1.1), \#225 Denver, CO (1.4), \#176 Philadelphia, PA-NJ (.95), \#146 Atlanta, GA (.77), \#175 Phoenix-Mesa, AZ (.95), \#9 Los Angeles-Long 
Beach, CA (.19), \#97 Houston, TX (.56), \#108 Washington, DC-MD-VA-WV (.59), \#73 New York, NY (.46), \#177 Chicago, IL (.96).

[22] A further interpretation of this interaction effect would be that in the hypothetical scenario where no immigrant workers are Hispanic, the presence of a $287(\mathrm{~g})$ agreement in an MSA has a negative effect on worker claims-making. Conversely, in those MSAs where there is no 287(g) agreement in an MSA, a proportionately larger Hispanic immigrant workforce predicts fewer claims. While main effects in later models (3-8) are positive, they are not significant at the conventional .05 level.

[23] Twenty-six MSAs have two offices, and 15 have three or more. Contrary to what one might think, the MSAs with multiple offices are not necessarily large global cities. Washington, DC-MD-VA-WC predictably tops the list with seven offices, but next in line is Minneapolis-St. Paul, MN-WI with five.

[24] These additional offices include: the Connecticut Commission On Human Rights \& Opportunities (109); Maine Human Rights Commission (17); Massachusetts Commission Against Discrimination (201); New Hampshire Commission for Human Rights (5); New York City Commission On Human Rights (25); New York State Division Of Human Rights (377); Rhode Island Commission For Human Rights (22); Civil

Rights Unit, VT Attorney General's Office (2); Boston Area Office (46); Newark Area Office (107); Buffalo Local Office (26).

[25] I also test for an interactive effect between the presence of a 287(g) agreement in the MSA, and the presence of an EEOC/FEPA office. The resulting effect is negative, but not statistically significant ( $\beta$ : $.082 ; \mathrm{p:} \mathrm{.666).}$

[26] This calculation is based solely on the categories enumerated here, as described in note 13 above.

[27] The Wage and Hour Investigative Support and Reporting Database (WHISARD) database is widely used and available, See: http://ogesdw.dol.gov/views/data_summary.php

[28] For an excellent collection of studies that coordinate workers' compensation reporting data, see work by Frank Neuhauser and colleagues at the University of California, UC DATA, http://ucdata.berkeley.edu/proj_list.php?recid=5.

[29] This analysis would require a request for federal data on workplace audits and E-Verify take-up (see, for example, Rosenblum 2011).

[30] Similar analyses have examined legal mobilisation in other arenas, such as the chilling effect of $287(\mathrm{~g})$ on immigrant women who are domestic violence victims (see for example, Quereshi 2010).

\section{References}

Abrego, Leisy J. 2008. "Legitimacy, Social Identity, and the Mobilization of Law: The Effects of Assembly Bill 540 on Undocumented Students in California." Law \& Social Inquiry 33 (3): 709-734. doi:10.1111/j.1747-4469.2008.00119.x.

American Community Survey. 2013. Guidelines for Data Users. http://www.census.gov/acs/www/guidance_for_data_users/estimates/ 
American Public Health Association. 2005. “Occupational Health and Safety Protections for Immigrant Workers." Policy Statement. Accessed December 14, 2005. http://www.apha.org/advocacy/policy/policysearch/default.htm?id=1318.

Amuedo-Dorantes, Catalina, Thitima Puttitanun, and Ana P. Martinez-Donate. 2013. "How Do Tougher Immigration Measures Affect Unauthorized Immigrants?" Demography 50: 1067-1091. doi:10.1007/s13524-013-0200-x.

Armenta, Amada. 2012. "From Sheriff's Deputies to Immigration Officers: Screening Immigrant Status in a Tennessee Jail." Law \& Policy 34 (2): 191-210. doi:10.1111/j.1467-9930.2011.00359.x.

Batalova, Jeanne. 2011. Foreign-Born Wage and Salary Workers in the US Labor Force and Unions. Washington, DC.http://www.migrationinformation.org/usfocus/display.cfm?ID=855\#3.

Bernhardt, Annette, Heather Boushey, Laura Dresser, and Chris Tilly. 2008. The Gloves-Off Economy: Workplace Standards at the Bottom of America's Labor Market. Ithaca, NY: ILR Press.

Bernhardt, Annette, Ruth Milkman, Nik Theodore, Douglas Heckathorn, Mirabai Auer, James DeFilippis, Ana Luz González, et al. 2009. "Broken Laws, Unprotected Workers: Violations of Employment and Labor Laws in America's Cities." Center for Urban Economic Development, National Employment Law Project, and the UCLA Institute for Research on Labor and Employment. http://nelp.3cdn.net/319982941a5496c741_9qm6b92kg.pdf.

Berrey, Ellen, Steve G. Hoffman, and Laura Beth Nielsen. 2012. "Situated Justice: A Contextual Analysis of Fairness and Inequality in Employment Discrimination Litigation." Law and Society Review 46 (1): 1-36. doi:10.1111/j.1540- 5893.2012.00471.x.

Best, Rachel Kahn, Lauren B. Edelman, Linda Hamilton Krieger, and Scott R. Eliason. 2011. “Multiple Disadvantages: An Empirical Test of Intersectionality Theory in EEO Litigation." Law \& Society Review 45 (4): 991-1025. doi:10.1111/j.1540-5893.2011.00463.x.

Bobo, Kim. 2008. Wage Theft in America: Why Millions of Working Americans Are Not Getting Paid And What We Can Do About It. New York: The New Press.

Borjas, George J., Jeffrey Grogger, and Gordon H. Hanson. 2008. “Imperfect Substitution between Immigrants and Natives: A Reappraisal." National Bureau of Economic Research w13887.http://www.nber.org/papers/w13887. 
Burstein, Paul. 1991. "Legal Mobilization as a Social Movement Tactic: The Struggle for Equal Employment Opportunity." The American Journal of Sociology 96(5): 1201-1225. doi:10.1086/229653.

Burstein, Paul, and Kathleen Monaghan. 1986. "Equal Employment Opportunity and the Mobilization of Law." Law \& Society Review 20 (3): 355-388. doi:10.2307/3053580.

Capps, Randy, Marc R. Rosenblum, Cristina Rodriguez, and Muzaffar Chishti. 2011. Delegation and Divergence: A Study of 287(g) State and Local Enforcement. Washington, DC. http://www.migrationpolicy.org/pubs/287g-divergence.pdf.

Chen, Ming Hsu. 2012. "Where You Stand Depends on Where You Sit: Bureaucratic Incorporation of Immigrants in Federal Workplace Agencies." Berkeley Journal of Employment and Labor Law 227(33): 227-298.

Cho, Eunice Hyunhye, and Rebecca Smith. 2013. Workers' Rights on ICE: How Immigration Reform Can Stop Retaliation and Advance Labor Rights (California Report), edited by NILC Statement. Washington, DC: National Immigration Law Center. http://www.nelp.org/page/Justice/2013/Workers-Rights-on-ICE-Retaliation-ReportCalifornia.pdf?nocdn=1.

Coursolle, Kathryn M., Lara L. Cleveland, and Steven Ruggles. 2013. "Variance Estimation in US Census Data from 1960-2000." Population Association of America Annual Meeting, New Orleans, LA, April 11.

Cummings, Scott. 2009. “Hemmed In: Legal Mobilization in the Los Angeles Anti-Sweatshop Movement." Berkeley Journal of Employment and Labor Law 30: 8-27.

Dadson, Nick. 2012. "The Real Immigrant-Native Wage Inequality." Metropolis British Columbia Centre of Excellence for Research on Immigration and Diversity No. 12-16. http://mbc.metropolis.net/assets/uploads/files/wp/2012/WP12-16.pdf.

Decker, Scott H., Paul G. Lewis, Doris M. Provine, and Monica W. Varsanyi. 2009. “On the Frontier of Local Law Enforcement: Local Police and Federal Immigration Law." In Immigration, Crime and Justice, vol. 13, edited by William F. McDonald, 261-276. Bingley: Emerald Group Publishing. 
Equal Employment Opportunity Commission. 2000. Memorandum of Understanding Between The Equal Employment Opportunity Commission and The Office of Special Counsel for Immigration Related Unfair Employment Practices. http://www.eeoc.gov/policy/docs/oscmou.html.

Equal Employment Opportunity Commission. 2014a. National Origin Discrimination. http://www.eeoc.gov/laws/types/nationalorigin.cfm.

Equal Employment Opportunity Commission. 2014b. Facts about National Origin Discrimination. Washington, DC. http://www.eeoc.gov/eeoc/publications/fsnator.cfm.

Felstiner, William L. F., Richard L. Abel, and Austin Sarat. 1980. "The Emergence and Transformation of Disputes: Naming, Blaming, Claiming." Law and Society Review 15 (3-4): 631-654. doi:10.2307/3053505.

Fine, Janice. 2006. Worker Centers: Organizing Communities at the Edge of the Dream. Ithaca, NY: ILR Press.

Fine, Janice, and Jennifer Gordon. 2010. "Strengthening Labor Standards Enforcement through Partnerships with Workers' Organizations." Politics \& Society 38(4): 552-585. doi:10.1177/0032329210381240.

Fine, Janice. 2011. "Worker Centers: Entering a New Stage of Growth and Development." New Labor Forum 20: 44-53.

Fisk, Catherine, Laura Cooper, and Michael J. Wishnie. 2005. "The Story of Hoffman Plastic Compounds, Inc. v. NLRB: Labor Rights Without Remedies for Undocumented Immigrants." Duke Law School Faculty Scholarship Series Paper 20.

Fox, Kimberly. 2009. "Building on a Broken Employer Sanction System: The Impact of the Bush Administration's SSA No-Match Letter Proposal." Harvard Law and Policy Review 3: 203.

Garcia, Ruben J. 2012. Marginal Workers: How Legal Fault Lines Divide Workers and Leave Them Without Protection. New York: NYU Press.

Gordon, Jennifer. 2007. Suburban Sweatshops: The Fight for Immigrant Rights. Cambridge, MA: Belknap Press. 
Griffith, Kati L. 2011a. “Discovering 'Immployment' Law: The Constitutionality of Subfederal Immigration Regulation at Work." Yale Law and Policy Review 29(389): 389-451.

Griffith, Kati L. 2011b. “ICE Was Not Meant To Be Cold: The Case For Civil Rights Monitoring Of Immigration Enforcement At The Workplace." Arizona Law Review 53 (4): 1137-1156.

Griffith, Kati L. 2012. “Undocumented Workers: Crossing the Borders of Immigration and Workplace Law." Cornell Journal of Law and Public Policy 21: 611-697.

Gritter, Matthew. 2012. Mexican Inclusion: The Origins of Anti-Discrimination Policy in Texas and the Southwest. Texas: A \& M University Press.

Guiraudon, Virginie, and Gallya Lahav. 2000. “A Reappraisal of the State Sovereignty Debate: The Case of Migration Control." Comparative Political Studies 33(2):163. doi:10.1177/0010414000033002001.

Hirsh, C. Elizabeth. 2014. "Beyond Treatment and Impact: A Context-oriented Approach to Employment Discrimination." American Behavioral Scientist 58(2): 256-273. doi:10.1177/0002764213503328.

Hirsch, Barry T., and David A. Macpherson. 2012. "Union Membership and Coverage Database from the CPS." Georgia State University and Trinity University. http://www.unionstats.com/.IPUMS-USA. 2013. Replicate Weights in the American Community Survey/Puerto Rican Community Survey. Minneapolis: Minnesota Population Center. https://usa.ipums.org/usa/repwt.shtml.

Justice for Carwash Workers. 2011. Derechos Laborales En LA. August 29. http://laborweb.aflcio.org/sites/Open5/carwash/index.cfm?action=article\&articl elD=2aa52738-7a8e-41ff-bcaf-fd97c53700a3.

Kostandini, Genti, Elton Mykerezi, and Cesar L. Escalante. 2012. "The Impact of Immigration Enforcement on the Farming Sector." In 2012 Annual Meeting, Seattle, Washington, August 12-14. Agricultural and Applied Economics Association.

Lacayo, A. Elena. 2010. "The Impact of Section 287(g) of the Immigration and Nationality Act on the Latino Community." National Council of La Raza 15.

http://www.nclr.org/index.php/publications/the impact of section $287 \mathrm{~g}$ of th e_immigration_and_nationality_act_on_the_latino_community/. 
Lahav, Gallya. 1998. "Immigration and the State: The Devolution and Privatisation of Immigration Control in the EU." Journal of Ethnic and Migration Studies 24(4): 674-694. doi:10.1080/1369183X.1998.9976660.

Lee, Stephen. 2011. “Monitoring Immigration Enforcement.” Arizona Law Review 53: 1089-1136.

Leitner, Helga, and Christopher Strunk. 2014. "Spaces of Immigrant Advocacy and Liberal Democratic Citizenship." Annals of the Association of American Geographers 104(2): 348-356. doi:10.1080/00045608.2013.875806.

Lewis, Paul, Marie Provine, Monica Varsanyi, and Scott Decker. 2013. "Why Do (Some) City Police Departments Enforce Federal Immigration Law? Political, Demographic, and Organizational Influences on Local Choices." Journal of Public Administration Research and Theory 23 (1): 125. doi:10.1093/jopart/mus045.

Martin, Nina. 2012. "'There Is Abuse Everywhere': Migrant Nonprofit Organizations and the Problem of Precarious Work." Urban Affairs Review 48 (3): 389-416. doi:10.1177/1078087411428799.

Massey, Douglas S. 2013. “Comment: Building a Better Underclass." Demography 50(3): 1093-1095. doi:10.1007/s13524-013-0204-6.

McCann, Michael W. 1994. Rights at Work: Pay Equity Reform and the Politics of Legal Mobilization. Chicago, IL: University of Chicago.

Merry, Sally Engle. 1990. Getting Justice and Getting Even: Legal Consciousness among Working-Class Americans. Chicago Series in Law and Society. Chicago: University of Chicago Press.

Milkman, Ruth. 2011. "Immigrant Workers, Precarious Work, and the US Labor Movement." Globalizations 8(3): 361-372. doi:10.1080/14747731.2011.576857.

National Conference of State Legislatures. 2014. Immigration. http://www.ncsl.org/research/immigration.aspx.

Nielsen, Laura B., and Robert L. Nelson. 2005. “Rights Realized? An Empirical Analysis of Employment Discrimination Litigation as a Claiming System." Wisconsin Law Review 2: 663-711.

Nielsen, Laura Beth, and Catherine Albiston. 2006. "The Organization of Public Interest Practice: 19752004." North Carolina Law Review 84 (5): 1591-1622. 
Nielsen, Laura Beth, Robert L. Nelson, and Ryon Lancaster. 2010. “Individual Justice or Collective Legal Mobilization? Employment Discrimination Litigation in the Post Civil Rights United States." Journal of Empirical Legal Studies 7(2): 175-201. doi:10.1111/j.1740-1461.2010.01175.x.

Ottaviano, Gianmarco I. P., and Giovanni Peri. 2008. "Immigration and National Wages: Clarifying the Theory and the Empirics." National Bureau of Economic Research No. w14188. http://www.nber.org/papers/w14188.pdf.

Parra-Garcia, Sabria. 2012. "Silicon Valley Women Demand Justice from Hyatt on Anniversary of 'Bikini Picture' Firings." Labor's Edge. October 12. http://www.calaborfed.org/index.php/site/page/silicon valley women demand justice_from_hyatt_on_anniversary_of_bikini_pic.

Parrado, Emilio A. 2012. "Immigration Enforcement Policies, the Economic Recession, and the Size of Local Mexican Immigrant Populations." The ANNALS of the American Academy of Political and Social Science 641 (1): 16-37. doi:10.1177/0002716211435353.

Pedriana, Nicholas, and Robin Stryker. 2004. "The Strength of a Weak Agency: Enforcement of Title VII of the 1964 Civil Rights Act and the Expansion of State Capacity, 1965-1971." American Journal of Sociology 110 (3): 709-760. doi:10.1086/422588.

Pham, Huyen, and Pham Hoang Van. 2010. "Economic Impact of Local Immigration Regulation: An Empirical Analysis." Immigration and Nationality Law Review 31: 687.

Quereshi, Ajmel. 2010. “287(g) and Women: The Family Values of Local Enforcement of Federal Immigration Law." Wisconsin Journal of Law, Gender \& Society 25: 261.

Rosenberg, Gerald N. 1991. The Hollow Hope: Can Courts Bring about Social Change. Chicago: University of Chicago Press.

Rosenblum, Marc R. 2011. E-Verify: Strengths, Weaknesses, and Proposals for Reform. Washington, DC. http://www.migrationpolicy.org/pubs/e-verify-insight.pdf.

Saucedo, Leticia M. 2010. “Immigration Enforcement versus Employment Law Enforcement: The Case for Integrated Protections in the Immigrant Workplace." Fordham Urban Law Journal 38 (1): 303-325. 
Singer, Audrey, Jill H. Wilson, and Brooke DeRenzis. 2009. Immigrants, Politics, and Local Response in Suburban Washington. Survey Series for the Metropolitan Policy Program.

Washington, DC: Metropolitan Policy Program at Brookings.

http://www.brookings.edu/ /media/research/files/reports/2009/2/25\%20immi gration\%20singer/0225_immigration_singer.pdf.

Singer, Audrey, Jill H. Wilson, and Brooke DeRenzis. 2009. Immigrants, Politics, and Local Response in Suburban Washington. Vol. Survey Ser. Washington, DC.

http://www.brookings.edu/ /media/research/files/reports/2009/2/25immigrati onsinger/0225_immigration_singer.pdf.

Smith, Rebecca, Ana Avendaño, and Julie Martinez Ortega. 2009. ICED OUT: How Immigration Enforcement Has Interfered with Workers' Rights. National Employment Law Project, AFL-CIO, and American Rights at Work Education Fund. http://www.americanrightsatwork.org/dmdocuments/ARAWReports/icedout re port.pdf.

Tamayo, William R. 1999. "Role of the EEOC in Protecting the Civil Rights of Farm Workers, The." UC Davis Law Review 33: 1075.

U.S. Immigration and Customs Enforcement. 2010. 287(g) Master Stats. Washington, DC. http://www.ice.gov/doclib/foia/reports/287g-masterstats2010oct31.pdf.

Varsanyi, Monica W., Paul G. Lewis, Doris Marie Provine, and Scott Decker. 2012. "A Multilayered Jurisdictional Patchwork: Immigration Federalism in the United States." Law \& Policy 34 (2):138-158. doi:10.1111/j.1467-9930.2011.00356.x.

Wishnie, Michael. 2004. "State and Local Police Enforcement of Immigration Laws." University of Pennsylvania Journal of Constitutional Law 4: 1084.

Wong, Tom K. 2012. "287(g) and the Politics of Interior Immigration Control in the United States: Explaining Local Cooperation with Federal Immigration Authorities."Journal of Ethnic and Migration Studies 38 (5): 737-756. doi:10.1080/1369183X.2012.667983. 